\title{
An analysis of relationship between food safety and pesticides usages of grape growers in Manisa province
}

\author{
Selçuk Karabat ${ }^{1}$ and Ela Atiş ${ }^{2}$ \\ ${ }^{1}$ Manisa Viticulture Research Station Dept. of Agricultural Economics, Manisa, Turkey \\ 2 Aegean University, Faculty of Agriculture, Dept. of Agricultural Economics, Izmir, Turkey
}

\begin{abstract}
This study was carried out in Manisa which has the largest vineyard areas and grape production of Turkey. In this research, awareness of environment and pesticide using attitudes of growers and effects on food safety of pesticides were investigated. Main data of the study was collected by survey from 117 grape growers which are settled in Manisa province where sultana production is very widespread. Applying Analytic Hierarchy Process (AHP), for reaching quality raisin and table grape target, conventional and environment friendly pesticides preference priorities were estimated. The AHP was applied to determine conventional and environment friendly pesticides usages of grape growers related to food safety. As a conclusion, it is understood that this target could be reached with $66.8 \%$ using environment friendly pesticides.
\end{abstract}

\section{Introduction and objectives}

The study was conducted in Manisa province that is biggest grape producer province of Turkey. The total vineyard area was 75401 hectares and the total grape production was 1114466 tons in 2013. Of the total grape production; 854117 tons were raisins (212 000 tons of raisins) and 260544 tons were table grapes. $87.49 \%$ of the raisins and $15.46 \%$ of the table grapes produced in Turkey were produced in the Manisa province [8].

Pesticides are commonly used on the food we eat to control pests that may damage the crops during production, storage or transport. Pesticides allow growers to increase the amount of usable food from each crop at the time of harvest. Pesticides may also improve the quality, safety, and shelf-life of certain foods. For consumers, this means access to a wide variety of affordable foods, grown locally or imported from other states or countries. Like other crops pesticides widely used for growing grapes. Also in Turkey grape growers use different kinds of pesticide groups. In this study a survey conducted and analyzed farmer's preferences in terms of food safety and pesticide use in Manisa province.

Main goals of this study,

- Determination of pesticide using preferences of growers between environment friendly and conventional pesticide groups

\section{Data and methodology}

In the study, three district of Manisa which were most important in grape production was selected. The survey population of this study was composed of table and raisin producers in these three districts. At the second stage, nine villages were selected on the basis of sultana production potential after interviewing some people and institutions who were expert of this subject.

Farmers preferences are based on the data collected in the study area. The data used in this study come from a survey of 117 farmers in Manisa province of Aegean Region. Survey was based on a standardized and pretested questionnaire. A pre-tested questionnaire consists of both open ended and closed ended questions and was used to collect data in face to face interviews. The survey questionnaire had subsections: The demographic and socioeconomic information, farm and marketing information and also the perceptions of the farmers.

Then, the AHP was applied to determine pesticide using preferences in terms of food safety of farmers related to quality, high price, production cost and marketing easily.

The AHP model was built by taking into account the pesticide using preferences of grape growers in terms of food safety and achieving high quality table grape and raisin. The AHP model for the growers' preferences is explained in Fig. 1.

\section{Explanation of Analytical Hierarchy Process (AHP)}

The AHP was developed by Thomas L. Saaty [6,7]. This model is one of the most commonly applied multicriteria decision making techniques $[2,5]$. The AHP is a decision-support tool to cope with complex multicriteria problems. The method helps to structure and analyze decision problems by breaking down the complex problem in a hierarchic order and by employing pair-wise comparisons of its elements to determine the preferences among the set of alternatives. The first stage of AHP is problem structuring. The AHP decision problem is structured hierarchically at different levels, each level 


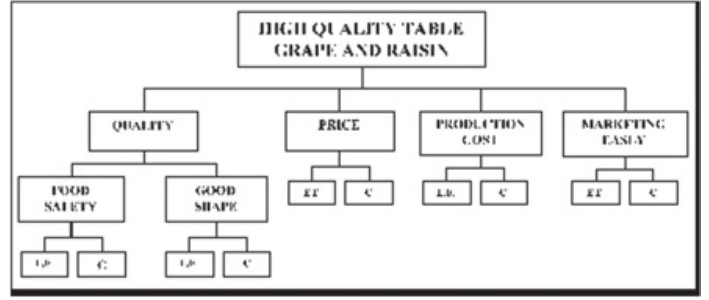

E.F.= Environmental Friendly Pesticide

$\mathrm{C}=$ Conventional Pesticide

Figure 1. Problem Definition of AHP Model.

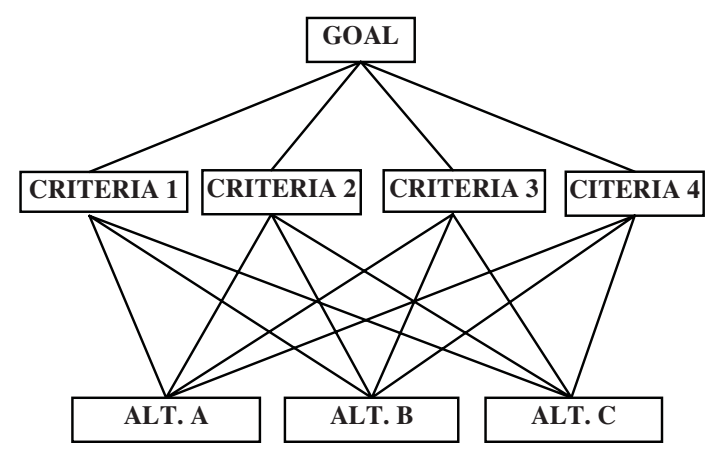

Figure 2. Sample AHP Model.

consists of a finite number of decision elements. A basic hierarchical model consists of a goal, criteria and alternatives. The top level of the hierarchy represents the overall goal, while the lowest level is composed of criteria and all possible alternatives. The second stage is assessment of local priorities. The relative importance of the decision elements is assessed indirectly from comparison judgments during the second step of the decision process. The third stage is calculation of global priorities. The last step of the AHP aggregates all local priorities from the decision table by a simple weighted sum [1-4].

\section{Findings and results}

In the AHP hierarchy system growers have pesticide choices like environmental friendly (EF) and conventional (C). Determination of Good Shape sub criteria, environmental friendly (EF) pesticides (0.577) are also more favorable than conventional (C) pesticides (0.423), but difference is not large compare to food safety sub criteria.

In terms of price and marketing easily criteries also tend the growers environment friendly pesticides groups. Only in tems of production cost criteria growers choice is conventional pesticides.

When we determine the importance of the criteria that influence the pesticide choices, Manisa grape growers are committed to the first marketing easily. Then comes quality, price and production cost criteria. Here is understood primarily growers that want to market their products in a way guaranteed, however, producing high quality grapes it is at least just as important.

Considering the food security and appearance criteria, Manisa grape growers, stated that the use of environment
Table 1. Determination of AHP Criteria and Choices.

\begin{tabular}{|l|l|l|l|l|}
\hline \multicolumn{5}{|l|}{ In terms of food safety sub criteria pesticide choices } \\
\hline $\begin{array}{l}\text { Pesticides } \\
\text { Choices }\end{array}$ & Min. & Max. & Avg. & $\begin{array}{l}\text { Std. } \\
\text { Dev. }\end{array}$ \\
\hline EF & 0 & 1 & 0.794 & 0.236 \\
\hline C & 0 & 1 & 0.206 & 0.236 \\
\hline In terms of good shape sub criteria pesticide choices \\
\hline EF & 0 & 1 & 0.577 & 0.194 \\
\hline C & 0 & 1 & 0.423 & 0.194 \\
\hline In terms of price criteria pesticide choices \\
\hline EF & 0 & 1 & 0.652 & 0.212 \\
\hline C & 0 & 1 & 0.348 & 0.212 \\
\hline In terms of production cost criteria pesticide choices \\
\hline EF & 0 & 1 & 0.451 & 0.280 \\
\hline C & 0 & 1 & 0.549 & 0.280 \\
\hline In terms of marketing easily criteria pesticide choices \\
\hline EF & .2 & 1 & 0.791 & 0.202 \\
\hline C & 0 & 0.8 & 0.209 & 0.202 \\
\hline In terms of quality criteria pesticide choices \\
\hline EF & 0 & 1 & 0.584 & 0.200 \\
\hline C & 0 & 1 & 0.416 & 0.200 \\
\hline
\end{tabular}

EF: Environment Friendly, C: Conventional.

Table 2. Determination of in terms of criteria for producing high quality grape.

\begin{tabular}{|l|l|l|l|l|}
\hline Criteria & Min. & Max. & Avg. & Std. Dev. \\
\hline Quality & 0.035 & 0.656 & $\mathbf{0 . 2 5 8}(\mathbf{2})$ & 0.163 \\
\hline Price & 0.057 & 0.631 & $\mathbf{0 . 2 2 5 ( 3 )}$ & 0.127 \\
\hline Production Cost & 0.033 & 0.582 & $\mathbf{0 . 1 5 1}(\mathbf{4})$ & 0.105 \\
\hline Marketing Easily & 0.086 & 0.717 & $\mathbf{0 . 3 6 6}(\mathbf{1})$ & 0.159 \\
\hline
\end{tabular}

Table 3. Determination of in terms of Quality Criteria Mix Priorities.

\begin{tabular}{|l|l|l|l|}
\hline Pesticide Choices & $\begin{array}{l}\text { Food Safety } \\
(\mathbf{0 . 5 8 4 )}\end{array}$ & $\begin{array}{l}\text { Good Shape } \\
(\mathbf{0 . 4 1 6})\end{array}$ & Mix \\
\hline EF & 0.794 & 0.577 & 0.704 \\
\hline C & 0.206 & 0.423 & 0.296 \\
\hline
\end{tabular}

EF: Environment Friendly, C: Conventional.

Table 4. Final Decision Matrix.

\begin{tabular}{|l|l|l|l|l|l|}
\hline $\begin{array}{l}\text { Pesticide } \\
\text { Choices }\end{array}$ & $\begin{array}{l}\text { Quality } \\
\mathbf{( 0 . 2 5 8 )}\end{array}$ & $\begin{array}{l}\text { Price } \\
\mathbf{( 0 . 2 2 5})\end{array}$ & $\begin{array}{l}\text { Prod. } \\
\text { Cost } \\
\mathbf{( 0 . 1 5 1 )}\end{array}$ & $\begin{array}{l}\text { Marketing } \\
\text { Easily } \\
\mathbf{( 0 . 3 6 6 )}\end{array}$ & Mix \\
\hline EF & 0.704 & 0.652 & 0.451 & 0.791 & $\mathbf{0 . 6 8 6}$ \\
\hline C & 0.296 & 0.348 & 0.549 & 0.209 & $\mathbf{0 . 3 1 4}$ \\
\hline
\end{tabular}

EF: Environment Friendly, C: Conventional.

friendly pesticides carry a priority for the production of high-quality grapes.

Finally, environmental friendly pesticides for grape growers to carry out the production of quality grapes according to all criteria could be said they saw a higher priority than conventional pesticides. 


\section{References}

[1] Atış E., B. Miran, K. Çiftçi, S. Karabat, 2013. An Analysis of Marketing Preferences of Sultana Producers in Turkey in Terms of Sustainable Market Power. 57th AARES Annual Conference, Sydney, New South Wales, 5th-8th February, 2013, Australia.

[2] Braunschweig, T., Becker, B., 2004, Choosing Research Priorities by Using the Analytic Hierarchy Process: An Application to International Agriculture, R\&D Management, 34, 1, 77-86

[3] Karabat, S., Atış, E., 2012. Manisa İli Bağ Alanlarında Kullanılan Tarımsal İlaçların Gıda Güvenliğine Etkisinin Koşullu Değerleme Yöntemiyle Analizi, Ege Üniversitesi Ziraat Fakültesi Dergisi, Cilt:49, sayı:1 Y11: 2012, S. 17-25.
[4] Prakash, T.N., 2003, Land Suitability Analysis for Agricultural Crops: A Fuzzy Multicriteria Decision Making Approach, International Institute For Geo-Information Science And Earth Observation, Enschede, The Netherlands

[5] Rommelfanger, H.J., 2003, A Fuzzy Logic Approach to Multicriteria Decision Making, Institute of Statistics and Mathematics, J.W. Goethe-University of Frankfurt Mertonstrasse, Frankfurt, Germany

[6] Saaty, L.T., 1980, The Analytic Hierarcy Procsess, McGraw-Hill Comp., U.S.A

[7] Saaty T.L. (2008) Decision making with the analytic hierarchy process, Int. J. Services Sciences, Vol. 1, No. 1

[8] Turkish Statistical Institute database 2013 